\title{
Sugar Profile of Syrups from Malted and Unmalted Rice of Different Varieties
}

\author{
Chigozie E. Ofoedu ${ }^{1}$, Chijioke M. Osuji ${ }^{1} \&$ Moses Ojukwu $^{1}$ \\ ${ }^{1}$ School of Engineering and Engineering Technology, Department of Food Science and Technology, Federal \\ University of Technology, Owerri, Nigeria \\ Correspondence: Chigozie E. Ofoedu, School of Engineering and Engineering Technology, Department of Food \\ Science and Technology, Federal University of Technology, P.M.B. 1526, Owerri, Imo State, Nigeria. Tel: \\ 234-706-316-8866. E-mail: chigozie.ofoedu@ futo.edu.ng
}

Received: November 6, 2018 Accepted: November 23, 2018 Online Published: January 16, 2018

doi:10.5539/jfr.v8n1p52

URL: https://doi.org/10.5539/jfr.v8n1p52

\begin{abstract}
Rice syrup was produced from ten varieties of locally available rice in Nigeria. Flours of malted and unmalted rice from different varieties were treated with a combination of starch hydrolyzing enzymes (Amyloglucosidase, Bacterial $\alpha$-amylase and Fungal $\alpha$-amylase); and the starch hydrolysates were either filtered and/or centrifuged at the end of hydrolysis. The resulting rice syrup was evaluated for sugar compositions (maltose, glucose, maltotriose, sucrose, raffinose and stachyose) using HPLC. The results showed that syrups from malted rice had significantly higher $(\mathrm{p}<0.05)$ maltose and maltotriose concentration than syrups from unmalted rice. The resultant syrup is a 'High Maltose Syrup' since maltose was found to be the predominant sugar in the rice syrup with concentration of above 50\% especially for malted samples. Rice syrup can be widely applied as a potential raw material in beverage and confectionery industries as well as a good adjunct for brewing since the sugar profile of the rice syrup was similar to that of barley wort.
\end{abstract}

Keywords: malted rice, rice hydrolysate, rice sugar, rice syrup, unmalted rice

\section{Introduction}

Syrups are defined as aqueous solutions of sugars or starch hydrolysates (International Food Information Service, 2005). It is a thick viscous liquid consisting primarily of dissolved saccharides in solution but showing little tendency to deposit crystals (Hull, 2010). The syrup viscosity is as a result of multiple hydrogen bonds between the dissolved sugars in aqueous solution, which have many hydroxyl $(\mathrm{OH})$ groups. Syrups are utilized as sweeteners in fruits drinks, liquors, bakery products, pharmaceuticals, and brewery products (International Institute of Tropical Agriculture, 2005).

Sugar (sucrose) is a refined sweetener used in formulation of many food and drinks to sweeten these products as well as add texture, body and bulk. Sucrose has been associated with health challenges such as contributing to obesity and keeping blood sugar out of balance (Kimball, 2011); therefore there is need to substitute them with unrefined sweeteners in various food products (Gibson, 2008; Vartanian, Schewartz \& Brownel, 2007), which may be a viable method for minimizing health challenges associated with the consumption of refined sweeteners. Furthermore, granulated sugar (sucrose) is expensive and it is used as the principal raw material in the production of beverages and confectionery products; as a result of this, there is need for a cheaper source of sweeteners. Also, sucrose can crystallize when used in some food products, thereby giving a coarse and gritty texture which may be unpleasant to the consumer; and so there is need to replace them with more functional sweeteners.

Starch is a major raw material for syrup production of low molecular weight products (glucose/dextrose, maltose, maltotriose and dextrin) (Selmi, Marion, Perrier-cornet, Douzals \& Gervais, 2000). Syrups are produced from different sources of starch, such as potato, cassava, amaranth and sorghum (Johnson \& Padmaja, 2013). Unfortunately, some indigenous starchy crops are not utilized for industrial syrup production. Though, some research works have been recorded on the use of some cereals (maize and sorghum) and tubers (cassava, sweet potato and yam) in syrup production, there is little or no information on the characteristics and properties of syrup from locally available rice. 
Rice can be used as raw material for the manufacture of various industrial products. Such products include starch, flour, ethanol, beverages and glucose syrup. Starch is a major raw material for the production of syrup and it is widely used in the food, pharmaceutical and confectionery industries (Zainab, Modu, Falmata, \& Maisaratu, 2010). The conversion of starch to various syrups can be achieved through a chemical (acid) or enzymatic process or both. The industrial processing of starch to glucose, maltose, maltotriose and dextrin involves gelatinization, liquefaction and saccharification processes using amylolytic enzymes (Hall, 2001). However, production of these important starch hydrolysates in Nigeria has been largely obtained from starch of tubers such as cassava whose cultivation is in large scale in the country (Aboje, 2007). Rice is also expected to play a major role in substituting the imported raw materials for syrup production as it is cultivated locally in various parts of Nigeria and is available all year round (Eke-Ejiofor, 2015). Therefore, the objective of this research work is to evaluate the sugar profile of rice syrup from malted and unmalted rice of different varieties.

\section{Materials and Methods}

\subsection{Sample Procurement}

Ten (10) different varieties of locally available rice were obtained from competent breeders and the rice varieties were a blend of improved varieties, indigenous and native rice. Four varieties of paddy rice (FARO 44, FARO 52, FARO 57 and FARO 61) were purchased from Biotechnology Research and Development Centre of Ebonyi State University (EBSU), Abakiliki. The other six varieties of paddy rice (Brown rice, IWA 3, Nwangenya, R8, Dragon 12 and 306) were obtained from local seed growers and were identified by the Biotechnology Research and Development Centre of Ebonyi State University, Abakiliki, Nigeria.

The processing of samples and experiments were carried out using the facilities available at the laboratory of Department of Food Science and Technology, Federal University of Technology, Owerri and at International Institute of Tropical Agriculture (IITA) Ibadan. Reagents and other chemicals used were of analytical grade.

\subsection{Enzyme Source}

Commercial exogenous enzymes (Fungal $\alpha$-amylase, Bacterial $\alpha$-amylase and Amyloglucosidase) were obtained from Novozyme company.

\subsection{Sample Preparation}

The rice paddy of different varieties was manually cleaned by sorting to remove extraneous materials and damaged seeds, followed by winnowing to remove dust.

\subsection{Malting of Rice}

The rice varieties were malted by adoption of barley malting protocols according to Kunze (2005) with slight modifications. Steeping of each sample was done at a temperature of $20-25^{\circ} \mathrm{C}$ for a period of 36 hours. The steep cycle involved alternating 12 hour wet-steep with 45 minutes air-rest period. After steeping, the grains were couched (heaped) on jute bags previously sterilized with dry heat. Samples were germinated within a temperature range of $25^{\circ}-30^{\circ} \mathrm{C}$, and samples were removed after the second day of germination. Kilning was performed in a hot air oven at temperatures between $60-70^{\circ} \mathrm{C}$ for about $2-3$ hours. Rice malt was continuously turned to aerate and achieve uniform controlled heat. Kilned samples were manually de-rooted by rubbing off with hand and winnowed to remove the rootlets and dust.

\subsection{Production of Rice Syrup}

The method of Osuji \& Anih (2011) with slight modification was used for the production of rice syrup. The malted/unmalted $(200 \mathrm{~g})$ rice flour from different varieties was dissolved in $800 \mathrm{ml}$ of water in a beaker that was previously brought to a $\mathrm{pH} 11.0$ with $\mathrm{Ca}(\mathrm{OH})_{2}$. The mixture was stirred continuously as the temperature was raised to $45^{\circ} \mathrm{C}$ and $0.4 \mathrm{ml}$ of Bacterial $\alpha$-amylase and Amyloglucosidase (AMG) each, were added into the sample as the temperature was maintained for 20 mins. With continuous stirring but not vigorous, the temperature of the sample mixture was raised to $55^{\circ} \mathrm{C}$ and maintained at this temperature for $10 \mathrm{~min}$. Conversion of the starch in the medium was evaluated by pipetting 2 drops of iodine solution on about $1 \mathrm{ml}$ of the sample, poured out on a white ceramic tile. More $0.4 \mathrm{ml}$ of Bacterial $\alpha$-amylase was added as the temperature of the contents of the beaker was raised to $65^{\circ} \mathrm{C}$ and maintained at this temperature for 1 hour. The second iodine test was done to estimate starch conversion. Furthermore, as the temperature of the sample mixture was raised to $90-93^{\circ} \mathrm{C}$, more $0.4 \mathrm{ml}$ of Bacterial $\alpha$-amylase was added and the contents of the beaker maintained at this temperature for 1 hour. The mixture was boiled for $5 \mathrm{mins}$ as the third iodine test was done. The temperature of the sample mixture was cooled to $60^{\circ} \mathrm{C}$ by placing in an ice water bath and the $\mathrm{pH}$ was checked and controlled to 5.7-5.8. Fungal $\alpha$ -amylase $(0.4 \mathrm{ml})$ was added to the mixture as the temperature of the mixture was maintained at $60^{\circ} \mathrm{C}$ for 1 hour. 
Another iodine test was carried out for starch conversion. A negative test for starch indicated that all the starch has been hydrolyzed. After hydrolysis the liquor was boiled for 10mins to denature enzymes. In one of the production processes, the converted slurry was filtered across a triple-layered muslin cloth while in the other process; the converted slurry was centrifuged at $1500 \mathrm{rpm}$ for $15 \mathrm{mins}$. The resultant filtrate and supernatant respectively was evaporated and packaged while the centrifuged concentrate (spent grain) was oven dried and packaged as described by Shaw \& Sheu (1992). The flow chart for this process is shown in figure 1.

\subsection{Sugar Analysis}

The evaluation of sugars using HPLC generally followed the process described in AOAC Official Method 982.14 (2006).

\subsection{Statistical Analysis}

Data obtained from this experiment was subjected to Analysis of Variance (ANOVA) using Statistical Package for Social Science (2006) version 16. The treatments were; Filtered Unmalted Hydrolyzed Rice (FUHR), Filtered Malted Hydrolyzed Rice (FMHR), Centrifuged Unmalted Hydrolyzed Rice (CUHR) and Centrifuged Malted Hydrolyzed Rice (CMHR). All analysis were performed in duplicates. Results were expressed as Mean \pm Standard Deviation (SD). Significant differences between means were separated by the least significant differences (LSD) at $\mathrm{p}<0.05$ between the sample parameters.

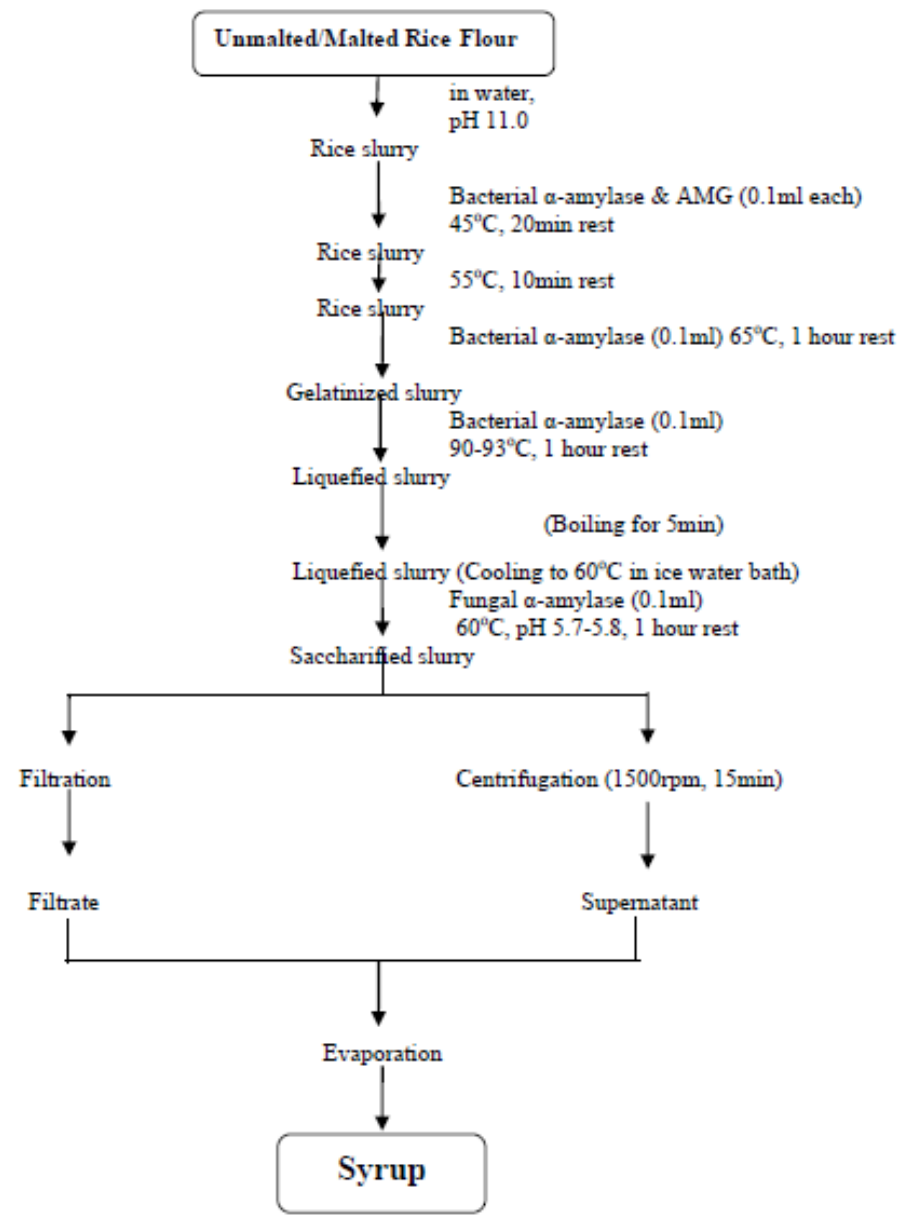

Figure 1. Flow diagram for the production of Rice syrup from malted and unmalted rice 
Table 1. Mean Values of the Sugar Profile of Rice Syrup

\begin{tabular}{|c|c|c|c|c|c|c|c|c|c|c|c|c|}
\hline \multirow[t]{2}{*}{ RICE VARIETIES } & \multicolumn{4}{|c|}{ MALTOSE (\%) } & \multicolumn{4}{|c|}{ GLUCOSE (\%) } & \multicolumn{4}{|c|}{ SUCROSE (\%) } \\
\hline & FUHR & FMHR & CUHR & CMHR & FUHR & FMHR & CUHR & CMHR & FUHR & FMHR & CUHR & CMHR \\
\hline 306 & ${ }^{2} 36.44^{\mathrm{e}} \pm 0.01$ & ${ }^{1} 62.36^{f} \pm 0.01$ & ${ }^{3} 34.67^{\mathrm{b}} \pm 0.01$ & ${ }^{1} 62.36^{f} \pm 0.01$ & ${ }^{1} 6.13^{\mathrm{a}} \pm 0.01$ & $2.59^{\mathrm{e}} \pm 0.01$ & ${ }^{2} 5.55^{\mathrm{e}} \pm 0.01$ & ${ }^{4} 2.37^{\mathrm{b}} \pm 0.01$ & ${ }^{1} 3.13^{\mathrm{f}} \pm 0.01$ & ${ }^{3} 0.75^{\mathrm{b}} \pm 0.01$ & ${ }^{2} 2.97^{\mathrm{e}} \pm 0.01$ & ${ }^{4} 0.64^{\mathrm{c}} \pm 0.01$ \\
\hline BROWN RICE & ${ }^{3} 36.66^{\mathrm{d}} \pm 0.01$ & ${ }^{1} 66.66^{\mathrm{a}} \pm 0.01$ & ${ }^{4} 33.26^{\mathrm{cd}} \pm 0.01$ & ${ }^{2} 64.48^{\mathrm{a}} \pm 0.01$ & ${ }^{1} 5.87^{\mathrm{f}} \pm 0.01$ & ${ }^{3} 2.26^{\mathrm{f}} \pm 0.01$ & ${ }^{2} 5.36^{\mathrm{g}} \pm 0.01$ & ${ }^{4} 2.06^{\mathrm{d}} \pm 0.01$ & ${ }^{1} 3.46^{\mathrm{C}} \pm 0.01$ & ${ }^{3} 0.56^{\mathrm{f}} \pm 0.01$ & ${ }^{2} 3.36^{\mathrm{b}} \pm 0.01$ & ${ }^{3} 0.53^{\mathrm{d}} \pm 0.01$ \\
\hline DRAGON 12 & ${ }^{3} 27.48^{\mathrm{i}} \pm 0.00$ & ${ }^{1} 38.06^{\mathrm{h}} \pm 0.01$ & ${ }^{4} 23.64^{\mathrm{e}} \pm 0.01$ & ${ }^{2} 35.37^{\mathrm{j}} \pm 0.01$ & ${ }^{1} 6.05^{b} \pm 0.01$ & ${ }^{3} 2.16^{\mathrm{g}} \pm 0.01$ & ${ }^{2} 5.63^{\mathrm{d}} \pm 0.01$ & ${ }^{4} 1.96^{\mathrm{e}} \pm 0.01$ & ${ }^{1} 2.88^{h} \pm 0.01$ & ${ }^{3} 0.73^{\mathrm{c}} \pm 0.01$ & ${ }^{2} 2.78^{\mathrm{g}} \pm 0.01$ & ${ }^{4} 0.64^{c} \pm 0.01$ \\
\hline FARO 44 & ${ }^{3} 35.34^{\mathrm{h}} \pm 0.01$ & ${ }^{1} 64.48 \pm 0.01$ & ${ }^{2} 33.36^{\mathrm{cd}} \pm 0.01$ & ${ }^{2} 57.35^{\mathrm{h}} \pm 0.00$ & ${ }^{1} 5.97^{\mathrm{d}} \pm 0.01$ & ${ }^{3} 3.05^{\mathrm{b}} \pm 0.01$ & ${ }^{2} 5.26^{\mathrm{h}} \pm 0.01$ & ${ }^{4} 2.26^{\mathrm{c}} \pm 0.01$ & ${ }^{1} 2.86^{\mathrm{i}} \pm 0.01$ & ${ }^{3} 0.56^{\mathrm{f}} \pm 0.01$ & ${ }^{2} 2.69^{\mathrm{h}} \pm 0.01$ & ${ }^{4} 0.47^{\mathrm{e}} \pm 0.01$ \\
\hline FAR0 52 & ${ }^{3} 35.36^{\mathrm{g}} \pm 0.01$ & ${ }^{1} 65.36^{\mathrm{b}} \pm 0.01$ & ${ }^{4} 32.67^{\mathrm{d}} \pm 0.01$ & ${ }^{2} 64.44^{\mathrm{b}} \pm 0.01$ & ${ }^{1} 5.03^{\mathrm{h}} \pm 0.01$ & ${ }^{3} 2.75^{\mathrm{c}} \pm 0.01$ & ${ }^{2} 4.55^{\mathrm{j}} \pm 0.01$ & ${ }^{3} 2.44^{\mathrm{b}} \pm 0.01$ & ${ }^{1} 3.23^{\mathrm{e}} \pm 0.01$ & ${ }^{3} 0.58^{\mathrm{e}} \pm 0.01$ & ${ }^{2} 3.16^{\mathrm{d}} \pm 0.01$ & ${ }^{4} 0.53^{\mathrm{d}} \pm 0.01$ \\
\hline FARO 57 & ${ }^{3} 36.86^{\mathrm{c}} \pm 0.01$ & ${ }^{1} 64.48^{\mathrm{c}} \pm 0.01$ & ${ }^{4} 34.56^{\mathrm{b}} \pm \mathrm{b} 0.01$ & ${ }^{2} 62.86^{\mathrm{d}} \pm 0.01$ & ${ }^{1} 6.06^{c} \pm 0.00$ & ${ }^{4} 2.68^{\mathrm{d}} \pm 0.01$ & ${ }^{2} 5.86^{\mathrm{a}} \pm 0.01$ & ${ }^{3} 2.29^{c} \pm 0.01$ & ${ }^{1} 3.46^{\mathrm{c}} \pm 0.01$ & ${ }^{3} 0.64^{\mathrm{d}} \pm 0.01$ & ${ }^{2} 3.36^{\mathrm{b}} \pm 0.01$ & ${ }^{4} 0.53^{\mathrm{d}} \pm 0.01$ \\
\hline FARO 61 & ${ }^{2} 36.66^{\mathrm{d}} \pm 0.01$ & ${ }^{1} 37.26^{\mathrm{i}} \pm 0.01$ & ${ }^{3} 35.76^{\mathrm{a}} \pm 0.01$ & ${ }^{2} 36.66^{\mathrm{i}} \pm 0.01$ & ${ }^{1} 5.97^{\mathrm{d}} \pm 0.01$ & ${ }^{2} 5.86^{\mathrm{a}} \pm 0.03$ & ${ }^{3} 5.78^{\mathrm{b}} \pm 0.01$ & ${ }^{4} 5.35^{\mathrm{a}} \pm 0.01$ & ${ }^{1} 3.58^{\mathrm{a}} \pm 0.01$ & ${ }^{3} 3.43^{\mathrm{a}} \pm 0.01$ & ${ }^{3} 3.44^{\mathrm{a}} \pm 0.01$ & ${ }^{4} 3.15^{\mathrm{a}} \pm 0.01$ \\
\hline IWA 3 & ${ }^{3} 37.16^{\mathrm{b}} \pm 0.01$ & ${ }^{1} 64.49^{c} \pm 0.01$ & ${ }^{4} 35.95^{\mathrm{a}} \pm 0.01$ & ${ }^{2} 63.96^{\mathrm{c}} \pm 1.41$ & ${ }^{1} 5.89^{\mathrm{e}} \pm 0.01$ & ${ }^{3} 2.74^{\mathrm{c}} \pm 0.01$ & ${ }^{2} 5.65^{\mathrm{c}} \pm 0.01$ & ${ }^{3} 2.26^{\mathrm{c}} \pm 0.01$ & ${ }^{1} 3.56^{\mathrm{b}} \pm 0.01$ & ${ }^{3} 0.76^{\mathrm{b}} \pm 0.01$ & ${ }^{2} 3.35^{\mathrm{b}} \pm 0.01$ & ${ }^{4} 0.66^{\mathrm{b}} \pm 0.00$ \\
\hline NWANGBENYA & ${ }^{3} 36.37^{\mathrm{f}} \pm 0.01$ & ${ }^{1} 63.36^{\mathrm{e}} \pm 0.01$ & ${ }^{4} 34.19^{\mathrm{bc}} \pm 0.01$ & ${ }^{2} 62.59^{\mathrm{e}} \pm 0.01$ & ${ }^{1} 5.06^{\mathrm{g}} \pm 0.01$ & ${ }^{3} 2.15^{\mathrm{g}} \pm 0.01$ & ${ }^{2} 4.97^{\mathrm{i}} \pm 0.01$ & ${ }^{4} 1.97^{\mathrm{e}} \pm 0.01$ & ${ }^{1} 3.36^{\mathrm{d}} \pm 0.01$ & ${ }^{3} 0.72^{c} \pm 0.01$ & ${ }^{2} 3.26^{\mathrm{C}} \pm 0.01$ & ${ }^{4} 0.66^{\mathrm{b}} \pm 0.01$ \\
\hline R8 & ${ }^{3} 37.46^{\mathrm{a}} \pm 0.01$ & ${ }^{1} 62.26^{\mathrm{g}} \pm 0.01$ & ${ }^{2} 34.06^{\mathrm{bc}} \pm 0.01$ & ${ }^{2} 60.48^{\mathrm{g}} \pm 0.01$ & ${ }^{1} 5.97^{\mathrm{d}} \pm 0.01$ & ${ }^{3} 2.75^{\mathrm{c}} \pm 0.01$ & ${ }^{2} 5.45^{\mathrm{f}} \pm 0.01$ & ${ }^{4} 2.36^{\mathrm{b}} \pm 0.01$ & ${ }^{1} 2.95^{\mathrm{g}} \pm 0.01$ & ${ }^{3} 0.52^{{ }^{g}} \pm 0.01$ & ${ }^{2} 2.88^{\mathrm{f}} \pm 0.01$ & ${ }^{4} 0.48^{\mathrm{e}} \pm 0.01$ \\
\hline LSD & 0.02 & 0.02 & 0.99 & 0.02 & 0.02 & 0.02 & 0.02 & 0.08 & 0.02 & 0.02 & 0.02 & 0.02 \\
\hline
\end{tabular}

Values are the means of duplicate determinations

a,b....means with the same superscript along a column for each treatment is not significantly different $(\mathrm{P}>0.05)$

$1,2 \ldots$ means with the same superscript within a row and within maltose, glucose and sucrose each is not significantly different $(\mathrm{P}>0.05)$

Note: FUHR=Filtered Unmalted Hydrolyzed Rice, FMHR=Filtered Malted Hydrolyzed Rice, CUHR=Centrifuged Unmalted Hydrolyzed Rice, CMHR=Centrifuged Malted Hydrolyzed Rice

Table 2. Mean Values of the Sugar Profile of Rice Syrup (Continued)

\begin{tabular}{|c|c|c|c|c|c|c|c|c|c|c|c|c|}
\hline \multirow[t]{2}{*}{ RICE VARIETIES } & \multicolumn{4}{|c|}{ MALTOTRIOSE (\%) } & \multicolumn{4}{|c|}{ RAFFINOSE (\%) } & \multicolumn{4}{|c|}{ STACHYOSE (\%) } \\
\hline & FUHR & FMHR & CUHR & CMHR & FUHR & FMHR & CUHR & CMHR & FUHR & FMHR & CUHR & CMHR \\
\hline 306 & ${ }^{3} 0.26^{\mathrm{b}} \pm 0.01$ & ${ }^{1} 9.56^{\mathrm{d}} \pm 0.01$ & ${ }^{4} 0.20^{\text {ef }} \pm 0.01$ & ${ }^{2} 9.36^{\mathrm{d}} \pm 0.01$ & ${ }^{1} 1.58^{\mathrm{b}} \pm 0.01$ & ${ }^{2} 0.26^{\mathrm{bc}} \pm 0.01$ & ${ }^{1} 1.58^{\mathrm{b}} \pm 0.01$ & ${ }^{2} 0.26^{\mathrm{bc}} \pm 0.01$ & ${ }^{2} 1.58^{\mathrm{d}} \pm 0.01$ & ${ }^{3} 1.08^{\mathrm{d}} \pm 0.01$ & ${ }^{1} 1.36^{\mathrm{f}} \pm 0.01$ & ${ }^{4} 0.36^{\mathrm{f}} \pm 0.01$ \\
\hline BROWN RICE & ${ }^{3} 0.29^{\mathrm{b}} \pm 0.14$ & ${ }^{1} 9.66^{\mathrm{d}} \pm 0.01$ & ${ }^{4} 0.26^{\mathrm{b}} \pm 0.01$ & ${ }^{2} 9.35^{\mathrm{d}} \pm 0.01$ & ${ }^{1} 1.63^{\mathrm{a}} \pm 0.01$ & ${ }^{2} 0.27^{\mathrm{b}} \pm 0.01$ & ${ }^{1} 1.63^{\mathrm{a}} \pm 0.01$ & ${ }^{2} 0.27^{\mathrm{b}} \pm 0.01$ & ${ }^{1} 1.69^{\mathrm{bcd}} \pm 0.01$ & ${ }^{3} 1.07^{\mathrm{d}} \pm 0.01$ & ${ }^{2} 1.44^{\mathrm{d}} \pm 0.01$ & ${ }^{4} 0.54^{\mathrm{d}} \pm 0.01$ \\
\hline DRAGON 12 & ${ }^{3} 0.24^{\mathrm{b}} \pm 0.01$ & ${ }^{1} 10.23^{\mathrm{b}} \pm 0.01$ & ${ }^{4} 0.19^{\mathrm{ef}} \pm 0.01$ & ${ }^{2} 9.98^{\mathrm{b}} \pm 0.01$ & ${ }^{1} 1.64^{\mathrm{a}} \pm 0.01$ & ${ }^{2} 0.22^{\mathrm{de}} \pm 0.01$ & ${ }^{1} 1.64^{\mathrm{a}} \pm 0.01$ & ${ }^{2} 0.22^{\mathrm{de}} \pm 0.01$ & ${ }^{1} 1.68^{\mathrm{bcd}} \pm 0.01$ & ${ }^{3} 1.08^{\mathrm{d}} \pm 0.02$ & ${ }^{2} 1.54^{\mathrm{c}} \pm 0.01$ & ${ }^{4} 0.45^{\mathrm{e}} \pm 0.01$ \\
\hline FARO 44 & ${ }^{3} 1.15^{\mathrm{a}} \pm 0.14$ & ${ }^{1} 8.66^{\mathrm{e}} \pm 0.01$ & ${ }^{4} 0.86^{\mathrm{a}} \pm 0.01$ & ${ }^{2} 7.54^{\mathrm{e}} \pm 0.01$ & ${ }^{1} 1.54^{\mathrm{c}} \pm 0.01$ & ${ }^{2} 0.20^{\mathrm{ef}} \pm 0.01$ & ${ }^{1} 1.54^{\mathrm{c}} \pm 0.01$ & ${ }^{2} 0.20^{\mathrm{e}} \pm 0.01$ & ${ }^{1} 1.86^{\mathrm{a}} \pm 0.01$ & ${ }^{4} 0.12^{\mathrm{e}} \pm 0.01$ & ${ }^{2} 1.75^{\mathrm{a}} \pm 0.01$ & ${ }^{3} 0.55^{\mathrm{d}} \pm 0.01$ \\
\hline FAR0 52 & ${ }^{3} 0.28^{\mathrm{b}} \pm 0.01$ & ${ }^{1} 9.96^{c} \pm 0.01$ & ${ }^{4} 0.24^{\mathrm{bc}} \pm 0.01$ & ${ }^{2} 9.67^{\mathrm{c}} \pm 0.01$ & ${ }^{1} 1.53^{\mathrm{c}} \pm 0.01$ & ${ }^{2} 0.25^{\mathrm{bc}} \pm 0.01$ & ${ }^{1} 1.53^{\mathrm{c}} \pm 0.01$ & ${ }^{2} 0.25^{\mathrm{bc}} \pm 0.01$ & ${ }^{1} 1.66^{\mathrm{bcd}} \pm 0.01$ & ${ }^{3} 1.18^{\mathrm{b}} \pm 0.01$ & ${ }^{2} 1.54^{\mathrm{c}} \pm 0.01$ & ${ }^{4} 0.44^{\mathrm{e}} \pm 0.01$ \\
\hline FARO 57 & ${ }^{3} 0.27^{\mathrm{b}} \pm 0.00$ & ${ }^{1} 10.35^{\mathrm{ab}} \pm 0.21$ & ${ }^{4} 0.25^{\mathrm{bc}} \pm 0.01$ & ${ }^{2} 0.27^{\mathrm{f}} \pm 0.00$ & ${ }^{1} 1.60^{\mathrm{b}} \pm 0.01$ & ${ }^{2} 0.24^{\mathrm{cd}} \pm 0.01$ & ${ }^{1} 1.60^{\mathrm{b}} \pm 0.01$ & ${ }^{2} 0.24^{\mathrm{cd}} \pm 0.01$ & ${ }^{1} 1.69^{\mathrm{bcd}} \pm 0.01$ & ${ }^{3} 1.13^{\mathrm{c}} \pm 0.01$ & ${ }^{2} 1.45^{\mathrm{d}} \pm 0.02$ & ${ }^{4} 0.55^{\mathrm{d}} \pm 0.01$ \\
\hline FARO 61 & ${ }^{2} 0.25^{\mathrm{b}} \pm 0.00$ & ${ }^{1} 0.28^{\mathrm{f}} \pm 0.01$ & ${ }^{2} 0.23^{\mathrm{cd}} \pm 0.00$ & ${ }^{2} 0.24^{\mathrm{g}} \pm 0.01$ & ${ }^{1} 1.63^{\mathrm{a}} \pm 0.01$ & ${ }^{2} 1.47^{\mathrm{a}} \pm 0.01$ & ${ }^{2} 1.47^{\mathrm{d}} \pm 0.01$ & ${ }^{3} 0.33^{\mathrm{a}} \pm 0.01$ & ${ }^{1} 1.86^{\mathrm{a}} \pm 0.01$ & ${ }^{2} 1.57^{\mathrm{a}} \pm 0.01$ & ${ }^{3} 1.39^{\mathrm{e}} \pm 0.01$ & ${ }^{4} 0.75^{\mathrm{b}} \pm 0.01$ \\
\hline IWA 3 & ${ }^{3} 0.25^{\mathrm{b}} \pm 0.01$ & ${ }^{1} 10.44^{\mathrm{a}} \pm 0.01$ & ${ }^{4} 0.18^{f} \pm 0.01$ & ${ }^{2} 10.27^{\mathrm{a}} \pm 0.14$ & ${ }^{1} 1.53^{\mathrm{c}} \pm 0.01$ & ${ }^{4} 0.18^{\mathrm{f}} \pm 0.01$ & ${ }^{2} 1.48^{\mathrm{d}} \pm 0.01$ & ${ }^{3} 0.26^{\mathrm{bc}} \pm 0.01$ & ${ }^{1} 1.74^{\mathrm{abc}} \pm 0.01$ & ${ }^{3} 1.13^{\mathrm{c}} \pm 0.01$ & ${ }^{2} 1.26^{\mathrm{g}} \pm 0.01$ & ${ }^{4} 0.55^{\mathrm{d}} \pm 0.01$ \\
\hline NWANGBENYA & ${ }^{3} 0.27^{\mathrm{b}} \pm 0.03$ & ${ }^{1} 10.27^{b} \pm 0.04$ & ${ }^{4} 0.21^{\mathrm{de}} \pm 0.01$ & ${ }^{2} 0.28^{\mathrm{f}} \pm 0.01$ & ${ }^{1} 1.48^{\mathrm{d}} \pm 0.01$ & ${ }^{2} 0.25^{\mathrm{bc}} \pm 0.01$ & ${ }^{1} 1.48^{\mathrm{d}} \pm 0.01$ & ${ }^{2} 0.25^{\mathrm{bc}} \pm 0.01$ & ${ }^{1} 1.76^{\mathrm{ab}} \pm 0.02$ & ${ }^{3} 1.15^{\mathrm{c}} \pm 0.01$ & ${ }^{2} 1.65^{\mathrm{b}} \pm 0.01$ & ${ }^{4} 0.68^{\mathrm{c}} \pm 0.01$ \\
\hline $\mathbf{R 8}$ & ${ }^{3} 0.23^{\mathrm{b}} \pm 0.01$ & ${ }^{1} 10.26^{\mathrm{b}} \pm 0.01$ & ${ }^{4} 0.18^{f} \pm 0.01$ & ${ }^{2} 9.97^{\mathrm{b}} \pm 0.01$ & ${ }^{1} 1.46^{\mathrm{e}} \pm 0.01$ & ${ }^{2} 0.24^{\mathrm{cd}} \pm 0.01$ & ${ }^{1} 1.45^{\mathrm{d}} \pm 0.01$ & ${ }^{2} 0.24^{\mathrm{cd}} \pm 0.01$ & ${ }^{1} 1.62^{\mathrm{cd}} \pm 0.17$ & ${ }^{2} 1.20^{\mathrm{b}} \pm 0.01$ & ${ }^{1} 1.63^{\mathrm{b}} \pm 0.01$ & ${ }^{3} 1.06^{\mathrm{a}} \pm 0.01$ \\
\hline LSD & 0.10 & 0.13 & 0.02 & 0.02 & 0.02 & 0.02 & 0.02 & 0.02 & 0.12 & 0.02 & 0.02 & 0.02 \\
\hline
\end{tabular}

Values are the means of duplicate determinations

a,b....means with the same superscript along a column for each treatment is not significantly different $(\mathrm{P}>0.05)$

$1,2 \ldots$...eans with the same superscript within a row and within maltotriose, raffinose and stachyose each is not significantly different $(\mathrm{P}>0.05)$

Note: FUHR=Filtered Unmalted Hydrolyzed Rice, FMHR=Filtered Malted Hydrolyzed Rice, CUHR=Centrifuged Unmalted Hydrolyzed Rice, CMHR=Centrifuged Malted Hydrolyzed Rice 


\section{Discussion}

The mean values of the sugar content of rice syrup from different varieties of rice processed by membrane filtration and centrifugation is shown in Table 1 and Table 2. The rice syrups yielded a combination of saccharides such as maltose, glucose, sucrose, maltotriose, raffinose and stachyose in various proportions. Malting generally caused a one fold increase in maltose but caused reduction in glucose and sucrose. The reduction in glucose was about $50 \%$ and the reduction in sucrose was by $75 \%$. This implies that maltose was probably generated during the malting process (unlike in syrups from unmalted rice) and also by hydrolytic enzymes during hydrolysis, while glucose and sucrose were being used up in the malting process to sustain the malt metabolism. Sucrose is a natural component of grains (Kulp \& Ponte, 2000) and it is not produced during malting or during hydrolysis. Kulp and Ponte (2000) reported that sucrose and glucose are major soluble sugars found in physiologically matured kernel. In addition, the germination process would have depleted the naturally occurring glucose and sucrose.

These observations were consistent for both centrifuged and membrane filtered syrup and the same pattern was observed for all rice varieties. The highest maltose, glucose and sucrose content were filtered malted hydrolyzed Brown rice $(66.66 \%)$, filtered unmalted hydrolyzed 306 rice variety $(6.13 \%)$ and Filtered unmalted hydrolyzed FARO 61 rice variety $(3.58 \%)$ respectively but the least maltose, glucose and sucrose content were centrifuged unmalted hydrolyzed Dragon 12 rice $(23.64 \%)$, centrifuged malted hydrolyzed Dragon 12 rice (1.96\%), centrifuged malted hydrolyzed FARO 44 rice variety $(0.47 \%)$ respectively. Some significant difference existed in the sugar profile of the syrup from filtered unmalted hydrolyzed rice, filtered malted hydrolyzed rice, centrifuged unmalted Hydrolyzed rice and centrifuged malted hydrolyzed rice; and amongst their respective rice varieties.

According to Ofoedu (2018), Brown rice recorded the highest germinative energy and germinative capacity while FARO 61 recorded the least germinative energy and germinative capacity. In line with the above statement, in this research work, it could be observed that Brown rice with the highest germinative energy and germinative capacity (Ofoedu, 2018) produced the highest maltose concentration for malted samples while FARO 61 with the least germinative energy and germinative capacity had the least maltose concentration for malted samples (Ofoedu, 2018; Okafor, Ofoedu, Nwakaudu and Daramola, 2019). The result also showed that low germinative energy and germinative capacity for FARO 61 generated syrup with the highest glucose and sucrose content for malted samples. The high glucose and sucrose content of FARO 61 when compared to other malted rice varieties could be because germination did not deplete the naturally occurring glucose and sucrose in grains which was evident in the low germinative energy and germinative capacity values of FARO 61. From this observation, it could be said that germinative energy and germinative capacity of cereals can be used as probable indicators in predicting the sugar concentration of its starch hydrolysates, depending on the type of enzyme used.

Maltotriose were present in larger proportions for syrups from malted rice compared to the syrups from unmalted rice. This observation follows the same trend as the maltose sugar results. The process of malting could have promoted enzymic changes leading to breakdown of starch to simpler sugars which includes maltotriose (Briggs, 1998). The significant difference $(\mathrm{p}<0.05)$ in maltotriose content also could have resulted from the enzymic activity during mashing.

The significant reduction $(\mathrm{p}<0.05)$ in raffinose content could have occurred during the malting and mashing processes leading to degradation of macromolecules. This explains why there was no reduction in raffinose content for the unmalted samples. The stachyose content did not show any particular trend which could imply that it was generally unaffected by the enzyme treatment, both exogenous and endogenous. It must have varied according to the genetic differences in the rice varieties used.

The comparatively lower maltotriose content for FARO 61 for the malted samples, matches the comparatively high raffinose content for the same samples. It therefore seems that the malting potential for FARO 61 might be lower than the other varieties and this was also observed in its germinative energy and germinative capacity (Ofoedu, 2018; Okafor et al., 2019).

The chromatograms of the different rice syrups obtained showed that maltose was the most abundant sugar in the syrup. This corroborates the findings of Palmer (2009) which reported that maltose was the most abundant sugar in wort. According to Palmer (2009), wort typically consists of only about $6 \%$ sucrose, with the rest being predominately maltose, maltotriose and larger dextrins. The high maltose concentration in the syrups could be due to the combination of bacterial $\alpha$-amylase and fungal $\alpha$-amylase enzyme used in the production of these syrups. According to Hull (2010), bacterial $\alpha$-amylase enzyme randomly attacks gelatinized starch at 1-4 linkages to produce glucose and maltose but unable to hydrolyze the 1-6 linkages. However, in this study, fungal $\alpha$-amylase was used as the saccharifying enzyme. Saccharification of starch involves the hydrolysis of 
oligosaccharides or dextrins produced after liquefaction to low molecular weight sugars such as glucose, maltose, or a mixture of these and their by-products (Bindumole \& Balagopalan, 2001). Furthermore, Hull (2010) reported that fungal $\alpha$-amylase attacks the 1-4 linkage of liquefied starch to produce predominately maltose, with lesser amounts of glucose. This provides an explanation for the high maltose concentration as compared to other sugars produced in the syrup. The high maltose concentration in the rice syrup could also be due to the ratio of amylose and amylopectin in the starch. This is in agreement with the findings of Shaw \& Sheu (1992) which reported that high amylose cultivars apparently produced maltose syrups containing more maltose.

From the results, it was also found that maltose and maltotriose concentration from malted samples (FMHR and CMHR) were significantly higher $(\mathrm{p}<0.05)$ than their corresponding unmalted samples (FUHR and CUHR). The observable increase in maltose and maltotriose concentration of FMHR and CMHR could be attributed to malting process. According to Goldhammer (2008), maltose and maltotriose are the most abundant sugars produced in malted grain when grain starch is modified. This corroborates the findings of Lodahl (1993) which reported that a typical sugar profile extract from malted barley is $50 \%$ maltose, $18 \%$ maltotriose, $10 \%$ glucose, $8 \%$ sucrose, $2 \%$ fructose and $12 \%$ higher carbohydrates including dextrins. According to Hull (2010), sugar syrups containing over 50\% maltose concentration are called High Maltose Syrup. It can be seen from Table 1 of this study that High Maltose Syrup can only be obtained by malting rice grains except for Dragon 12 and FARO 61.

The concentration of glucose and sucrose in syrups from both malted and unmalted rice was apparently generally reduced after hydrolysis when compared to starch hydrolysate profile of other works. Furthermore, the observable decrease in glucose concentration in the rice syrup could also be attributed to the type of enzyme used at the saccharification stage. Chaplin (2014) reported a glucose concentration of $97 \%$ and $4 \%$ when glucoamylase and fungal $\alpha$-amylase were used respectively as the saccharifying enzyme in production of syrup. The above statement is in line with the findings of Hull (2010) which also reported that glucoamylase also known as amyloglucosidase (AMG) is an enzyme capable of hydrolyzing both the 1-4 and 1-6 linkages to produce glucose and it is therefore sometimes referred to as a saccharifying enzyme; but in this study, fungal $\alpha$-amylase was used as the saccharifying enzyme which explains the reduction of glucose concentration as reported by Chaplin (2014).

On the other hand, the reduction in sucrose concentration could also be as a result of transformation of sucrose by cross linking with raffinose and stachyose. Raffinose is a trisaccharide composed of galactose, glucose and fructose unit (Storey, Noiles \& Thompson, 1998), while stachyose is a tetrasaccharide consisting of glucose, fructose and two galactose units (Nakakuki, 2002). They are called $\alpha$-galactosides and are found in legumes and whole grains (Storey et al., 1998). Nsofor and Osuji (1997) reported the occurrence of cross linkages of soy solutes in soymilk from sprouted soybeans. Osuji and Okafor (2013) also reported the cross linking of soymilk components from three varieties of soybean. Alais and Linden (1999) explained that plant oligosaccharides such as ajucose, verbascose, stachyose and raffinose are usually tied to one glucose unit through the 1-6 bonding and have the affinity to be cross linked to sucrose. It is possible that the new $\alpha$-galactosides derived from the hydrolysis of rice oligosaccharides might have been engaged in linkages with sucrose by this described affinity. This is in agreement with the statement of (Abo-Elmagd, 2013) who reported that raffinose and stachyose are $\alpha$ -galactosides of sucrose. Osuji and Okafor (2013) reported that when sugars are transformed or cross linked, their physical characteristics are altered and their wavelengths of light absorption may change and they can escape detection. This therefore provides explanation for the reduction of sucrose concentration in the rice syrup when compared to previous works. The results also showed that the raffinose and stachyose concentration from malted samples (FMHR and CMHR) were significantly lower $(\mathrm{P}<0.05)$ than their corresponding unmalted samples (FUHR and CUHR). The decrease in concentration of raffinose and stachyose of FMHR and CMHR could also be attributed to malting process. The oligosaccharides are degraded during seed germination by the action of two distinct types of $\alpha$-galactosidase that differ in their optimal $\mathrm{pH}$ of catalysis. While the acid $\alpha$-galactosidase type is most likely active in the acidic environment of the vacuole and apoplasm, the alkaline $\alpha$-galactosidase type probably catalyzes galactose release in the more neutral or alkaline cytoplasm (Carmi et al., 2003; Lee, Lin \& Chen, 2004).

\section{Conclusion}

The method for high quality syrup production from different varieties of locally available rice was established. Malting of rice improved the hydrolysis and modification of its starchy endosperm and also generally increased the maltose concentration of rice syrups produced from different locally available rice varieties in Nigeria to above 50\%. Therefore, such syrups having maltose as the predominant sugar with a concentration of 50\% are regarded as "High Maltose Syrup". Generally, filtration and centrifugation showed no significant effect on the 
sugar profile of resultant rice syrups. Rice syrup can be widely applied as a potential industrial raw material for different food products such as bread and snacks in confectionery industry, as adjuncts in breweries and in ice cream production.

\section{Acknowledgement}

This research was supported by Tertiary Education Trust Fund (TETFUND) of the Federal Republic of Nigeria through Federal University of Technology, Owerri (FUTO). The enzymes were supplied by Novozymes Company.

\section{References}

Abo-Elmagd, H. I. (2013). Hydrolysis of galacto-oligosaccharides in soymilk by immobilized $\alpha$-galactosidase from Chaetomium madarasense AUMC 9376. Romanian Biotechnological Letters, 19(1), 9028-9041.

Aboje, P. (2007). Production and Export of Glucose from cassava starch. Retrieved from http://www.independentngonline.com/news/190/article/18394/2007/01/06.html

Alais, C., \& Linden, G. (1999). Food Biochemistry. Aspen Publishers, Inc. Maryland. pp. 33-34.

AOAC (2006). Official Method 982.14 "Official Methods of Analysis". $18^{\text {th }}$ Edition.Horwitz W, George LW (Eds.), Association of Official Analytical Chemists, Maryland.

Bindumole, V. R., \& Balagopalan, C. (2001). Saccharification of sweet potato flour for ethanol production. Journal of Root Crops, 27(1), 89-93.

Briggs, D. E. (1998). Malts and Malting. Springer. pp. 369-389.

Carmi, N., Zhang, G., Petreikov, M., Gao, Z., Eyal, Y., Granot, D., \& Schaffer, A. A. (2003). Cloning and functional expression of alkaline $\alpha$-galactosidase from melon fruit; similarity to plant SIP proteins uncovers a novel family plant glycosyl hydrolases. Plant Journal, 33, 97-106. https://doi.org/10.1046/j.1365-313X.2003.01609.x

Chaplin, M. (2014). The use of Enzymes in Starch Hydrolysis. Retrieved from http://www.isbu.ac.uk/biologv/enzlech/glucose.html

Eke-Ejiofor, J. (2015). Functional Properties of Starches, Physico-Chemical and Rheological Properties Of Glucose Syrup Made From Cassava And Different Potato Varieties. International Journal of Recent Scientific Research, 6(1), 4400-4406.

Gibson, S. (2008). Sugar-sweetned soft drink and obesity: A systematic review of the evidence from observational studies and invention. Nutrition Research, 21(2), 134-147. https://doi.org/10.1017/S0954422408110976

Goldhammer, T. (2008). The Brewer's Handbook, $2^{\text {nd }}$ ed., Apex.

Hall, M. B. (2001). Factors Affecting Starch Analysis of Feeds. Retrieved from http://edis.ifas.ufl.edu/AN102

Hull, P. (2010). Glucose syrups: Technology and Application. Wiley Blackwell Publishers. https://doi.org/10.1002/9781444314748

IFIS (2005). Dictionary of Food Science and Technology: International Food Information Service. Blackwell Publishers.

IITA (2005). Glucose Syrup. In: Integrated Cassava Project. Published by International Institute of Tropical Agriculture (IITA) UNICEF Joint Scheme Nigeria.

Johnson, R., \& Padmaja, G. (2013). Comparative Studies on the Production of Glucose and High Fructose Syrup from Tuber Starches. International Research Journal of Biological Sciences, 2(10), 68-75.

Kimball, K. (2011). A Sweet, Sweet Summer: Why is White Sugar bad for you?. Retrieved from http://www.kitchenstewardship.com/2011/07/22/a-sweet-sweet-summer-why-is-white-sugar-bad-for-you

Kulp, K., \& Ponte, J. G. (2000). Handbook of Cereal Science and Technology, Second Edition, Revised and Expanded. Marcel Dekker, Inc. pp. 153-154.

Kunze, W. (2005). Technology Brewing and Malting. VLB, Berlin. pp. 110.

Lee, R. H., Lin, M. C., \& Chen, S. C. (2004). A novel alkaline $\alpha$-galactosidase gene is involved in rice leaf senescence. Plant Molecular Biology, 55, 281-295. https://doi.org/10.1007/s11103-004-0641-0

Lodahl, M. (1993). Malt Extracts: Cause for Caution, Brewing Techniques. New Wine Press, 1(2). 
Nakakuki, T. (2002). Present status and future of functional oligosaccharide development in Japan. Pure and Applied Chemistry, 74(7), 1245-1251. https://doi.org/10.1351/pac200274071245

Nsofor, L. M., \& Osuji, C. M. (1997). Stability, Rheology and Chemical Properties of Soymilk Concentrate Developed from Sprouted Soybean. Journal of Food Science and Technology, 34(1), 33-36.

Ofoedu, C. E. (2018). Evaluation of Syrup Quality from Malted and Unmalted rice varieties. (Unpublished master's thesis). Federal University of Technology, Owerri, Nigeria.

Okafor, D. C., Ofoedu, C. E., Nwakaudu, A., \& Daramola, M. O. (2019). Enzymes in Food Biotechnology. Production, Applications and Future Prospects. In: Enzymes as Additives in Starch Processing: A Short Overview Elseivier Inc., Academic Press. pp. 149-168. https://doi.org/10.1016/B978-0-12-813280-7.00010-4

Osuji, C. M., \& Anih, P. O. (2011). Physical and Chemical Properties of Glucose Syrup from Different Cassava Varieties. Nigerian Food Journal, 29(1), 83-89.

Osuji, C. M., \& Okafor, D. (2013). Effect of Combined Cell Wall Degrading Enzyme Treatment on the Total Dissolved Solids and Sugars of Soymilk. The Annals of the University Dunarea de Jos of Galati Fascicle VI - Food Technology, 37(1), 50-60. http://doi.org/10.13140/RG.2.2.24967.09126

Palmer, J. (2009). Attenuation: Advanced Brewing. Retrieved from http://byo.com/malt/item/1895-attenuation-advanced-brewing

Selmi, B., Marion, D., Perrier-cornet, J. M., Douzals, J. P., \& Gervais, P. (2000). Amyloglucosidase Hydrolysis of High-pressure and Thermally Gelatinized corn and wheat starches. Journal of Agriculture and Food Chemistry, 48(7), 1-5. https://doi.org/10.1021/jf991332u

Shaw, J. F., \& Shew, J. R. (1992). Production of High Maltose Syrup and High Protein Flour of Rice by an Enzymatic method. Japanese Society for Bioscience, Biotechnology and Agrochemistry, 56(7), 1071-1073. https://doi.org/10.1271/bbb.56.1071

SPSS (2006). Statistical Package for Social Science (SPSS, 16). Window Evaluation Version, U.S.A.

Storey, B., Noiles, E., \& Thompson, K. (1998). Comparison of Glycerol, other polyols, Trehalose and Raffinose to provide a Defined Cryoprotectant medium for mouse sperm Cryopreservation. Cryobiology, 37(1), 46-58. https://doi.org/10.1006/cryo.1998.2097

Vartanian, I. R., Schewartz, M. B., \& Brownel, K. D. (2007). Effect of soft drink consumption on nutrition and health: a systematic review and Meta-analysis, American Journal of Public Health, 97(4), 667-675. https://doi.org/10.2105/AJPH.2005.083782

Zainab, A., Modu, S., Falmata, A. S., \& Maisaratu, P. (2010). Laboratory scale production of glucose syrup by the enzymatic hydrolysis of starch made from maize, millet and sorghum. Biokemistri, Nigerian Society for Experimental Biology, 23(1), 1-8.

\section{Copyrights}

Copyright for this article is retained by the author(s), with first publication rights granted to the journal.

This is an open-access article distributed under the terms and conditions of the Creative Commons Attribution license (http://creativecommons.org/licenses/by/4.0/). 